\title{
GYÖRGY KÁLMÁN*
}

\section{The Problematics of Economic Law in the Works of Gyula Eörsi}

\begin{abstract}
The essay deals with the debates in Hungary concerning economic law at the beginning of the 1950s. At the time when socialist law penetrated into Hungary, many raised the issue whether economic law could be the adequate branch of law in socialist law. However, as the concept of economic law was defeated in the Soviet Union at the late 1930s, economic law could not be carried on even in Hungary. The essay provides a survey of the fights concerning Hungarian economic law, with special regard to the works of Gyula Eörsi.
\end{abstract}

Keywords: economic law, socialist legal science

I.

It is not my purpose here to expound, neither in an international nor in a Hungarian perspective, the history of the ideological debate about 'economic law', undoubtedly the keenest debate in the history of socialist law which had even tragic consequences.

I seek to expose how Gyula Eörsi, unquestionably the greatest Hungarian civilist of his age, arrived from the initial strong opposition-through the ingenious idea of the 'internal and external complexity of law', to mention it in advance-to the de facto recognition of economic law without having to give up his former theoretical position in any respect.

As human views and scientific propositions cannot be understood without knowing the context: the given age, its atmosphere and the consequential concrete events, at the beginning I shall briefly deal with the character of Hungarian legislation and legal literature in the years after liberation in 1945, the fall of the theory of economic law (which in my view didn't even exist), the cause and origin of this fall, and the history of this subject at the end of the thirties in the Soviet Union.

"György Kálmán, H-1132 Budapest, Visegrádi u. 9. Hungary.

Fax: (36 1) 4745185 
The history of the formation and fall of Soviet 'economic law' is presented in detail in Contribution to the Theory of Enterprise Law by Tamás Sárközy, so I don't need to touch upon the topic even in a general perspective.

On the basis of contemporary legal literature and my personal remembrance I would remark that 'economic law', as formed in the Weimar era and continued under Hitler in Germany or as established in the Soviet Union in the 1920's was in this sense non-existent in Hungary.

There hasn't been any Hungarian theory of economic law (the only exception will be treated below) in spite of the use of the term. The term referred to economically relevant positive law on the one hand and the literature interpreting this legal material for legal professionals and the nonlawyer economic specialists on the other.

It is well known and a commonplace that in 1945 Hungary inherited a destroyed economy and a severe inflation. Using the phrase of the time, economic reconstruction was then the crucial link in the chain. This reconstruction, as well as the execution of agrarian reform needed a greatscale legislation. The problems of the 'abandoned goods' waited for solution too, to cite only one example from the long list. The work of reconstruction was linked to the introduction of socialism, initiated already in 1946 with the nationalisation of big banks. It is clear that the focus of legal literature was directed on this topic. Not only the articles of legal journals but also books concentrated on the subject, and after 1947 monographs appeared one after the other dealing with the regulation of the economy, with the term 'economic law' in their title in some form. From 1947-48 on these books and articles referred to the socialist character of the legal material.

However, these books were handbooks without any dogmatics. In any case, there couldn't have been any dogmatics in them, because it simply didn't exist.

The need for these works has been later (after 1951 when the witchhunt abated) recognised even by the opponents of economic law, moreover their re-edition has been urged (they didn't appear for a long time after the end of forties).

In 1948 the Hungarian Lawyers' Association was formed through the unification of several organisation of lawyers. On this occasion a great international conference was held in Hévíz with the participation of foreign delegations. As usual, the conference worked in sections and of course there was also a section for economic law. A Soviet delegation participated at the conference too. The leader of this delegation, Professor Manjkovsky took notice from the programme with surprise that there was a section for economic law and pointed out to the organisers of the conference and to the 
participating leaders of legal life that economic law was rejected in the Soviet Union at the end of thirties as a Trotskyte and anti-socialist tendency.

It needed a piece of time for his warning to begin to take effect. In 1949 and 1950 the term 'economic law' was still used in Hungarian legal literature. Moreover, in 1950 Miklós Világhy held a lecture in the Lawyers' Association with the title Our Constitution and Economic Law. ${ }^{1}$ In his

1 The principal statements of his lecture were the following:

"Our Constitution certainly expresses and fixes the achievements of the development of economic law, determines the foundations of economic law and marks the main trends of future development as well. Which are these foundations and trends?

a) According to section 4 paragraph 1 of our Constitution, in the People's Republic of Hungary the bulk of the productive assets is in public ownership. Though productive assets may be hold by private persons, the working people-continues paragraph 2 of the aforementioned section-gradually displaces capitalistic elements and steadily builds the socialist economic order.

From these stipulations of our Constitution we have to draw two conclusions regarding the material of economic law. The first conclusion is that in the structure of our national economy, those enterprises and other organisational forms that hold each a group of the publicly owned productive assets came to have a determinative weight.

The second conclusion is that among the rules governing the operation of people's economy, the process of social economic administration, those which regulate public enterprises, or in general the operation, production and trade performed by the units of public economy, predominate and gain more and more ground.

After the detailed examination of the relation between the constitution and economic law, finally we have to ask the question again: what gives the importance of the constitution for economic law. In the introduction we have answered that the constitution, among others, summarises the main directions for the development of economic law in the people's democracy. It is evident that now, after the detailed analysis we have a more precise answer. Along the detailed analysis we have seen that in the field of organisational law the development of economic law of the people's democracy brought about the establishment of the basic principles of socialist enterprise organisation, and the development is expected to continue in the same direction. In the law of exchange, the result of development is the emergence of the main legal guarantees of socialist plan discipline and the legal regulation of the contract of delivery. We have seen in the law of co-operatives that our legal system is on the way toward the realisation of the different forms of socialist-type co-operatives. Finally, in labour law, we have stated that the constitution declares the basic principles of socialist labour law and determines its main safeguards as well. The economic law of our people's democracy is today of socialist type not only through its character but, for the most part, on the crucial points it has developed to socialist economic law regarding its content and the origin of its rules too. The Constitution of the People's Republic of Hungary reflects this economic law of socialist content, summarises the achievements of its development, 
monograph of 1951 entitled The Problem of Economic Law, written in the spirit of the era but with a very high professional legal culture, he rejected economic law and went as far as to call out for the banishment of economic law from the education of non-lawyer economic specialists.

At the end of 1950 was published the Hungarian translation of Visinsky's The Problems of Soviet Legal and Political Science, which rejected economic law declaring it Trotskyte and anti-socialist.

The Committee for Legal and Political Science of the Hungarian Academy of Sciences put the question of economic law on the agenda.

During the debate on economic law, not limited to the Committee for Legal and Political Science of HAS, there were only some persons to hold aloft the banner of socialist economic law, already with knowledge of the antecedents in the Soviet Union. Among them was György Vadas, the first deputy-director of the Institute of Legal and Political Science of HAS, who paid for his deed not only with his position at the Institute but also with his scientific carrier. During the debate, Vadas explained: it is possible that they have chosen a bad name for the subject analysed in their books but it is not identical neither to German imperialist nor to so-called "Trotskyte" Soviet economic law.

Following the resolution of the Committee for Legal and Political Science of HAS which rejected economic law, was published Miklós Világhy's monograph The Problem of Economic Law. This work, using the phraseology of the day but reflecting the fine legal culture of the author, analysed the problematics of economic law in six chapters, from the beginnings of commercial law in Europe to the critique of the Hungarian theory of economic law (which theory, in my view, did not exist). The author stressed with

and marks the main trends of the further development. This is the essence and importance of the relation of the constitution and economic law.

b) According to Section 5 of our Constitution, the economic life of the Hungarian People's Republic is determined by the national economic plan.

From this stipulation of our Constitution, we can draw again two conclusions regarding the material of economic law. The first states that due to the development in the last few years, the material of our economic law has been broadened by the rules regulating the determination of the national economic plan and the planned operation of the economy. This broadening is not only a simple increase in quantity but - and this is our second conclusion - a qualitative change too. The centre of gravity of exchange law, law of production and trade of goods is no more the material of trade transactions, commercial sale, consignment, shipment and other so-called commercial transactions." Világhy, M.: Alkotmányunk és a gazdasági jog (Our Constitution and Economic Law). Budapest, 1950. 
emphasis that the scholars of Hungarian economic law (among them the author himself with his co-authored secondary school textbook in 1949, his articles and lectures) can be identified subjectively neither with the scholars of German imperialist economic law nor with mischievous Soviet economic lawyers, the subject of their scholarly work, however, objectively leads to the destruction of the socialist legal system. ${ }^{2}$

In his monograph, representing the culmination of the campaign against economic law, Miklós Világhy divides the (not too voluminous) literature on economic law in groups according to the year of publication $(1948,1949$, 1950) and a bit forcibly refers to some qualitative differences among them. Namely

1948: the beginning of the theory of economic law,

1949: the accomplishment of the theory of economic law,

1950: the appearance of fully-fledged socialist theory of economic law.

${ }^{2}$ Világhy summarises his charges against the Hungarian "theory" of economic law as follows:

a) The question of economic law is primarily not a problem about the legal system but for the most part, a question about the character of the popular democratic law and state, about the soundness of the general views on the popular democratic law and state. The Hungarian theory of economic law made serious mistakes in this respect, since

aa) it supposed that there are parts of different character, of different class content within our popular democratic system of law,

bb) did not recognise the position of the individual in the socialist state, especially the inseparable linkage of socialist forms of ownership and it set socialist state and its economy against the individual citizen.

b) Economic law is secondarily also a question of the socialist legal system. The Hungarian economic law theory made a serious mistake when it endeavoured to unite the legal rules on economy in a separate branch of law, because

aa) in this way it separated certain groups of pecuniary relations of the socialist society from other groups of pecuniary relations,

bb) mutilated these pecuniary relations through the exclusion of property and consumption,

cc) the enlargement of the material of economic law is ineffectual since it would result in a heterogeneous legal material without any unifying principle,

dd) the theory of economic law proceeded also wrongly by trying to set the material of economic law on the basis of political economy since in this way, it misrepresented the proper relation of basis to superstructure, especially legal superstructure, and gave a false account of the nature and the characteristics of the legal superstructure. Világhy, M.: A gazdasági jog problémája (The Problem of Economic Law). Magyar Jogász Szövetség, Budapest, 1951. 
He states the following: the theory of economic law of 1950 declares itself self-consciously and decidedly a complete socialist theory, a representative of socialist legal science which endeavours consistently to apply the Marxist-Leninist scientific method. ${ }^{3}$

II.

There is only one theoretical statement in the history of Hungarian economic law after the liberation in 1945. György Vadas namely wrote in his work The Outlines of Economic Law, published in autumn 1950 the following:

"The material of our economic law is held together by the solid steelworks of socialist political economics. We cannot make serious mistakes, cannot loose touch with reality if we endeavour to cast light on the material of our economic law by the laws of political economics. [...] We strive to sum up our legal institutions according to the basic features of the political economics of socialism." ${ }^{4}$

Gyula Eörsi joined the debate at this question of systematisation. In his article "Economic Law and Political Economy", published in the November 1951 issue of Jogtudományi Közlöny [Journal for Legal Science] and based on his contribution of 5 July, 1951 at the discussion on economic law in the Committee for Legal and Political Science of HAS, Eörsi refuted Vadas' views. His main argument was that to treat the material of economic

${ }^{3}$ By 1950, the most important characteristics of this theory got fully mature. These characteristics are

- the conception that legal rules relating to social economy mount up to a separate self-contained branch of law,

- the view that economic law practically cuts through the material of a host of other branches of law, separating and embracing in itself every rule that has some linkage to economic life (e.g. the law of economic administration, the part of criminal law dealing with economic crimes, parts of procedural law that are closely related to economic life, the entire financial law, the entire labour law); so economic law appears indeed as an expansive branch of law which deprives other branches of their material, takes the air away from them.

- the view that the whole economic law, or at least its basic part reflects the main idea, the "regulating principle" of planificatedness, the opposition of planification and plan discipline to freedom of contract. (Világhy: ibid.)

${ }^{4}$ Vadas Gy.: A gazdasági jog vázlata (The Outlines of Economic Law). Budapest, 1950 . 
law in the system of political economics did not advance the presentation of the interrelation of basis and the material of economic law.

But Vadas was wrong in that he tried to squeeze the material of economic law, being in close connection to the economic basis, in the system of political economics that is treating with this basis. The economic basis is the basis indeed but political economics is nothing else but a system of views: a superstructure.

The material of economic law cannot be separated from other legal material and transposed in the system of political economics because law, the entire legal system is an autonomous (though not independent) system.

Eörsi's view is different from the view of Világhy and the Soviet literature against economic law in that he does not hold economic law for 'expansive law':

"It does not follow from the aforesaid that economic law should be expansive and should divert the law of ownership from private law. As I mentioned in one of my previous articles, it follows rather that as the so called economic law is devoid of the basis, treated in private law, the autonomy of the so called economic law should be terminated and the appropriate part of economic law should be incorporated in private law." 5

Practising economic specialists and the main part of legal professionals concerned by the material of economic law did not have any idea of this debate on economic law. The more interested and qualified lawyers working in the 1950's of economy were at a loss toward the debate. In the first half of the fifties, after Világhy's book, written with fine legal culture but still blowing the icy wind of witch-hunt, they remained numb and silent. Later they only smiled and considered the whole debate as a university fight of legal theorists around professorships. That is, they did not understand why economic law cannot be a mixed branch of law if labour law does; what is the reason for the autonomy of land law and the law of agricultural cooperatives as a branch of law (not only as a separate university field of study) while economic law is not an autonomous branch of law, not even a main course at the university. To be sure, later on several special courses were dealing with economic law both within the field of private and administrative law but to avoid to "fall into sin", to call a spade, they were held under different intricate titles, specially as long as Világhy still had word and influence in university education.

\footnotetext{
5 Eörsi, Gy.: Gazdasági jog és politikai gazdaságtan (Economic Law and Political Economics). Jogtudományi Közlöny VI 1951 No. 11, 671-675.
} 
The rather unilateral 1951 debate was followed by a long during silence. The problem of economic law scarcely came into question in the literature until the preparations of the 1968 reform of economic administration.

After the death of Stalin the study of economic law recommenced in the GDR and Czechoslovakia and in the latter even an Economic Code was introduced. This was reflected in the Hungarian legal literature at the beginning of the sixties as Mihály Samu treated the recognition of the autonomy of economic law sympathetically in his monograph on the structure of the legal system and several civilists, including Gyula Eörsi though continued to reject economic law but already on the basis of cool professional arguments, wholly devoid of witch-hunt.

In 1967, the last preparation year before the economic reform began a new debate on economic law on the columns of the journal Magyar Jog [Hungarian Law].

Practising lawyers, among them Iván Meznerics, distinguished also as a theoretician, urged for the recognition of economic law, again not as calling for a separate dogmatics or a comprehensive code but as a demand for the recognition of the coherence and complexity of this field of law and especially of the adequate importance of economic law in the literature for practising lawyers as well as in the education.

At this time Eörsi reacted negatively to the demand for the recognition of economic law. I remember an (unpublished) impromptu contribution of his at a meeting, chaired by Rezső Nyers, in which he answered to the contributions of economists calling for the recognition of economic law. He exposed that even if there might have been place for autonomous economic law in a system of economic administration based on breaking down the plan which was combining the method of administrative commands and civil contracts, there is no place for it in the new system of direction which reject the method of plan and breaking down and is based on the autonomous organising role of contracts.

Eörsi expounded his view systematically in his monograph On the Law of the Switch-over to a New System of Economic Administration, published in 1968.

In this work he does not mention yet internal and external complexity or the complex method but there appears the idea that the codification of private law shall be based on the specificities of the contract relations of socialist organisations and the specificities required by mass production shall be reflected in auxiliary acts, decrees and fundamental trading conditions of a complex character. 
"Thus our conclusion is that the 'economic law oriented' conception of codification which proposes an autonomous code, co-ordinated to the Civil Code is not the best method to regulate legal relations of the people's economy. The same holds for the 'commercial law oriented' solution which equally urges a separate code for the regulation of legal relations of the people's economy but in which the Civil Code would be the background law for this separate code. Against these two conceptions the conception of a unitary Civil Code shall be accepted, reorganised on the level of codification in the necessary measure according to the model of socialist organisations. The specificities deriving from the socialist character of the people's economy and from mass production shall be reflected in auxiliary acts, government decrees and fundamental trading conditions of a complex character. This offers the required stability and mobility for the legal material of the people's economy. However, it is evident that an economic code is in no way more mobile than the civil code."

The reason for Eörsi to reject economic law was invariably his persistent view that the systematic division of law shall rest on legal and not directly on economic reality.

The system of law cannot be built directly on economic reality. Though in the last resort determined by economy, law is a relatively independent system of views and institutions. ${ }^{7}$

"The difference between the traditional and the 'economic law oriented' conceptions lies not in that the traditional conception uses highly abstract concepts (property, legal person, contract etc.) as some representatives of economic law alleges, but in that the traditional socialist conception thinks in legal institutions while the socialist conception of economic law thinks in economic activities. So the latter reasoning is regrettably far too obvious within the circle of non-lawyers, among whom especially economists have an extremely great influence on decisions which irradiate to law as well.

It follows that such statements according to which the growth of economic law to a separate branch of law is the same phenomenon as the separation of labour law, the law of co-operatives or family law as independent branches of law, cannot be substantiated. In these we are dealing with small collectives; by this way the unity of social relations shows up clearly and

${ }^{6}$ Eörsi, Gy.: A gazdaságirányítás új rendszerére való áttérés jogáról (On the law of the Switch-over to a New System of Economic Administration). Budapest, 1968. 133.

Id. $88-89$. 
also unitary legal principles and methods come to existence, fitting to the relations of the small collective. But in the domain of economic law there is no such perspective because as Világhy pointed out, economic law does not embrace the economy; that's why its boundaries can be laid out only arbitrarily." $"$

Thus after all this said, we have to conclude that on the level of codification, the most convenient solution, for this country too, is a single civil code. This solution on the level of codes implies also that, on the basis of codes, which are separated mainly according to legal branches, auxiliary acts, government decrees and fundamental trading conditions shall be created, to meet the requirement of complexity and greater variability. ${ }^{9}$

III.

Eörsi's outstanding theory on "internal and external complexity" which was leading to the gradual recognition of economic law without retracting his former theoretical position was comprehensively expounded for the first time in $1972 .^{10}$

Already in the introduction he is more indulgent toward the conception of economic law than the Hungarian literature till then.

"Present-day conceptions of economic law are based on a particular interpretation of economic determination and service role of law. They declare a certain scheme of economic activity for the backbone of the system of law, directly attach legal provisions to economic institutions, brings law 'closer to the practice'.

So even the most determined opponents of economic law can not say that it is only about an infectious mistake." 11

Eörsi noted that the adherents of the conception of economic law and of civil law and administrative law were dealing with the same material. Their references were at variance not because they put different theoretical straitjackets on facts. The thing is that there was a difference between evaluations. For systematisation the first group emphasised economic structure, the second

${ }^{8}$ Id. 32.

${ }^{9}$ Id. 133.

${ }^{10}$ Eörsi, Gy.: Külső és belső komplexitás. A gazdasági jog kérdéséhez (External and Internal Complexity. On the Question of Economic Law). Gazdaság és Jogtudomány, MTA IX. Osztályának Közleményei. Budapest, 1972.

${ }^{11}$ Id. 81 . 
accentuated legal institutions. The very close connection between state regulation of the economy and the administration of public property was clear for everyone. Some considered this fact as constituting branches of law, others did not, but both had a common purpose: more effective legal assistance for people's economy and the society.

Eörsi sketched two models of the mechanism of people's economy. The first-essentially the model of GDR-conceived the entire people's economy as a single immense centrally operated "machinery". The secondessentially the Hungarian model—was a "system" achieving the dynamic equilibrium within a space regulated by the national economic plan.

In the "machinery" model legal elements constitute internal complexity, in the "system" model external complexity.

By internal complexity he means that legal units integrate elements which are heterogeneous from the perspective of legal function and method (e.g. elements of civil and administrative law) - this is the conception of economic law. External complexity means that legal institutions essentially retain their contour and branch-of-law specificities. The institutions of different branches of law operate together without dissolving, in a way that they maintain their functional and methodical characteristics. The "machinery" model is the hotbed of internal complexity (the economic law) because it essentially consists in the mingling of administrative and economic elements, i.e. administrative law and civil law. External complexity corresponds to the "system" model as it separates administrative and economic, i.e. administrative law and civil law elements. Internal complexity is reflected in the branches of law as the maintenance of the traditional socialist division of the legal system.

So, Eörsi relates the "machinery" model to the conception of internal complexity and economic law and the "system" model to the conception of external complexity. It is not the same as to link economic law to the planned economy with direct commands and the traditional socialist conception to indirect, decentralised systems, viz. to contend that the situation in socialist states before the reforms encourages economic law while the situation after reforms is favourable to the conception of external complexity. This view, which previously also Eörsi himself advocated, is to some extent simplifying and contradicts certain facts. It is very easy to grasp the system of direct plan commands by the conception of external complexity: this was the predominant practice in the law of European socialist states. It is not direct plan command system which is favourable to economic law but the "system" model, although, as we shall see, internal complexity, i.e. economic law leads almost by nature to the dominance of 
centralism. Hence, the conceptions of internal and external complexity connect not with direct and indirect economic administration mechanisms but with "machinery" and "system" models.

One of the important differences between the two conception subsisting on this common ground is the following: The conception of internal complexity which realises staatliche Leistungspyramide, is conceived in a vertical crosssection. Every relevant theoretical construction is built from the peak of central organs to the base, by its nature with a strong orientation toward central elements. Market can find a place in this construction only artificially as it would imply, within the conditions of socialism, the "system" instead of "machinery".

In contrast, the conception of external complexity is neutral from the point of view of orientation. Within this conception vertical and horizontal cross-sections as well as the internal relations of firms and co-operatives can be distinguished. In this way a space is created within which the current economic administration may determine the place and importance of different elements. The conception of external complexity is equally apt for the service of a more centralised directive mechanism and a decentralised one with a considerable role for the regulated market.

The second important divergence of the two conceptions is essentially that they attach law to economy on different levels.

Of course, the conception of external complexity seeks to influence economic processes too but in this respect the conception of internal complexity is specific inasmuch as it directly adjusts the legal system to the regulation of the economic process. The machinery of staatliche Leistungspyramide needs to attach law to certain elements of the economic mechanism at a considerably lower level so that the autonomous system of law loses importance. There is no sense to think about institutions of law here.

In contrast, according to the conception of external complexity law serves the economic mechanism as a specifically legal system based on legal institutions, operates comprehensive legal abstractions and attaches great importance to the institutions of law.

The conception of internal complexity is $a$ ) linking the most divergent legal means to each element of the economy and in this way $b$ ) substitutes an economic system for the specific legal system, thinning away the legal element on a great scale. Often the writings on economic law can be hardly distinguished from practical economic works: instead of institutions of law they primarily deal with legal means attached to economic ends, methods and organisation. 
In contrast, the conception of external complexity considers the relative autonomy of law as a condition of the development of special, characteristically legal means and so the more effective service of the economy; that is what the conception of internal complexity denies.

It involves, however, that the conception of internal complexity is hardly suitable for becoming the conception of codification since a code is characterised by the systematisation of a large area in law, i.e. it embraces law in a legal system. But, as explained, there is no much place for the legal system within the conception of internal complexity. It is due to this fact that in the country which enforces this conception the most consequently, the GDR, the great difficulties with the codification led at least temporarily to renounce to establish an economic code and to regulate the people's economy on government level, through a fragmented and not a unitary system. Meanwhile the codification of the civil code was being continued. In Czechoslovakia the Economic Code was effectively an act on economy systematised according to the branches of the people's economy. Under the title "general provisions" only 26 sections out of 400 comprised the provisions on the relations of direction. Other provisions were such that for the most part they could equally take place within a socialist civil law codification: 272 sections related to the law of obligations, all of them appertaining except for 43 sections to the particular provisions of the law of obligations. ${ }^{12}$

In the final account, legal regulation of the people's economy means the regulation of human activity, though it necessarily contains a great number of purely technical element. The legal element not only provides the official sanction for the economic element but transposes the ends posited and processes designed by economists and engineers. That is a not unimportant reason for the existence of law as a specific establishment, i.e. one which is not identical to its determinant, the economic system. This being granted, the "machinery" or "system" character of the economic mechanism orientates in different directions. The conception of internal complexity intended for the service of the "machinery" is dominated by the "regulation of processes". In the conception of external conception, intended for the service of the "system" the "regulation of activities" is dominant. In turn, the prominence of the regulation of activities brings about the prominence of the legal system.

Eörsi points out two practical shortcomings of the conception of internal complexity. It does not take into account that civil law contracts need some common provisions, nor that a great number of contract types equally

${ }^{12} I d .90-92$. 
apply for the public property sector and the personal property sector (credit, carriage, insurance, lease, deposit etc.).

The conception of economic law, however, cannot include the common provisions about contracts, only the provisions for those concluded between socialist organisations.

According to the conception of internal complexity the integrity, namely practical economic integrity is formed by the obligations of the people's economy; contracts between socialist organisations and individuals or between individuals themselves are excluded. For the conception of external complexity, however, the unity is made out of all commodity-related obligations (which relate relatively autonomous parties) irrespective of subjects and sectors; this excludes in turn the systematic integrity with the obligations deriving from the relations of governmental economic direction and of intra-firm management.

The replacement of the legal system by a system based on the scheme of economic activity or organisation leads to split asunder institutions of law through the denial of systematising relevancy of high-order generalisations (socialist property law, contract of commodity or autonomous structure, responsibility etc.). The conception of internal complexity comes nearer to the everyday practice than the conception of external complexity does, both in the choice of its system, of the still useful level of generalisation and in the tendency of descending from the level of institutions of law to the level of legal rules. Before considering this as an absolute advance let us remind that the system nearest to the practice is that of the common law; it cannot see the wood for the trees, becomes pragmatist and remains in spheres that provide a natural medium for theoretical indifference. This of course does not hold for the conception of internal complexity; on the contrary, the manifestations in the GDR are the most ideological; but from a legal perspective, the result of these considerations come close to practicism because they tend to see in law nothing more than an administrativetechnical auxiliary device of the economic practice.

The final conclusion of the work is that the compilation and especially the codification of the entire legal material of the people's economy is both unnecessary and impossible. It is unnecessary because nobody needs it in entirety. He who works as lawyer in the construction industry does not need the whole system of rules for internal commerce. It is also impossible because legal activity reaches back to general institutions overlapping the scope of economy (delay, invalidity, termination etc.).

While the conception of internal complexity commingles legal instruments at the outset and causes the sketched problems in theory, policy of law and 
practice in this way, the key issue of the conception of external complexity is to find the suitable level, measure and method to junction the institutions of different branches of law in the different areas of legal work: legislation, jurisprudence and legal education etc. This is a practical problem in all these domains.

Different tools does not become similar as being used in the work on the same object: drill remains drill and hammer remains hammer. We have to manufacture and get the mastery of both tools separately but we have to apply them together. That is the essence of the conception of external complexity.

Thus in this work of Eörsi we cannot find the recognition of economic law even as a secondary branch of law or as a discipline.

In spite of this, Eörsi's theory of internal and external complexity gave full satisfaction to the needs of lawyers working in different fields. These lawyers were repugnant and at a loss toward the debate about the qualification of economic law as a branch of law from the beginning.

They held for natural to unite legal institutions of the economy in a harmonic construction irrespective of their place within the branches of law. Eörsi's theory, determining the content of external complexity satisfied this need. They considered this theory as the recognition of the coherent work in the different domains of economic law and of the unconditional necessity of this work. The debate on the rejection or recognition of the autonomy of this branch of law was looked upon, a bit sceptically as one about the establishment of another professorship. None of these lawyers raised a claim to duplicate the general part of the law of obligations as it was done in Czechoslovakia by framing the Economic Code. But they surely claimed for the recognition and the legislative expression of the specialities of economic contracts by the framing of an economic code. They used in this respect a trivial but sound argument: although the re-soling of a shoe and the complete construction of a nuclear power plant are both realised through a contract of enterprise there is a great difference both in the content and the legal characteristics of the two contracts.

After the reforms of 1968 Eörsi already accepted that by the regulation of the particular contract types in the Civil Code the requirements of the contracts important for the people's economy shall be taken into account as rules and the contracts for mere consumption shall be reckoned with when determining the exceptions.

Why did the theory of internal and external complexity satisfy the needs of legal practitioners?

1. A practising lawyer is cognisant of the importance of the limits between criminal law and civil law, substantive law and procedural law, 
recognises the speciality of political law as a separate branch of law in the conditions of socialism but beyond that he does not care about the division of branches of law. For him it is indifferent whether law reflects the economy by internal complexity, i.e. by an autonomous branch of law or by external complexity i.e. by the harmony of institutions of law established within separate branches of law.

2. They needed an accord among different legal institutions of the economy, that the important gaps of law shall not be filled or the collision of legal rules within different branches of law shall not be resolved by the practice. The theory fulfilled this need.

3. This theory recognised also in civil law the dominance of economic phenomena by the formation of principal rules.

The theory of complexity allowed for the silent, orderly and peaceful retreat of legal theoreticians in this stormy question.

In my view the theory of complexity was, even before its full exposition in 1977, a de facto recognition of economic law without theoretical retreat. That makes the theory ingenious.

IV.

The further development of the theory of internal and external complexity is due to a further advance on the way of de facto recognition of economic law. Eörsi's last monographic work, Law, Economy and the Structure of the Legal System was published in $1977 .{ }^{13}$

As a point of departure he made a remark on the relation of law and extra-legal social phenomena. Law always regulates social relationships which do not respect its system. That lies behind the enchantedness of law, as Imre Szabó expressed it. However, the intensity of the state-controlled plan economy pushed this problem to the extremes. Instead of the regulation of behaviour, norms relating to the economy contain regulations characterised by the enumeration of a great number of parameters.

"The structure of the legal system unites the internal and external aspects of law in a self-referring manner with respect to the structure of the special legal sphere: in reality we are dealing with the organisation of the 'external' (socio-economic relations) into a heterogeneous 'internal' system (the law). From the point of view of the special characteristics of

\footnotetext{
${ }^{13}$ Eörsi, Gy.: Jog - gazdaság - jogrendszer-tagozódás (Law, Economy and the Structure of the Legal System). Budapest, 1977.
} 
law, the legal system shall be, as we will treat it at length, a closed system of logic, while a branch of law shall form a legally regulated complex of socio-economic relations into a sub-system. Thus, the type of socio-economic relations and the legal regulation, i.e. the 'external' and the 'internal', the social and the legal aspects are equally important for us. It is quite obvious that economic law, for instance takes into consideration only the first aspect. What concerns the specifically legal element, there is a danger here, that of legal formalism which may lead to a mere logical system. It can be avoided by not isolating the specifically legal element, as law cannot be isolated from the subject it refers to. Law shall be considered as determined by society in order to bring to bear its social effects in an optimal way. Thus the specific character and mechanism of law come into prominence. Socio-economic relations, otherwise groupable in a number of ways, shall be sorted into branches of law according to their identical or similar legal character and mechanism. That's what law as a specific objectivation requires and the character of these socio-economic relations itself plays an important role in the grouping." 14

The structure of the legal system is thus given by the dialectics of socio-economic relations and the specific legal method. Based on this, the arrangement is determined by this pair of phenomena as filtered by cognitive and volitional media of legislation and jurisprudence and as finally expressed across certain fractures.

The traditional theorem which says that the structure of the legal system is divided on the basis of certain groups of social relations and specific legal methods, is not exact entirely. These two are not joined together by an 'and', because in real these are the external and internal side of the same thing. Although on the final account social relations determine law, the way it happens will substantially depend on the specificities of law, i.e. the methods which are available. From an external perspective the social relations are determinant, from an internal view, the legal methods. The social relation can determine the structure of the legal system on the final grade only by "putting on the dress of law", by adapting to legal specificities.

Eörsi drew a difference between the structure and the division of the legal system:

"Beyond the aforementioned double determinant of its structure, the division of the legal system is specified by every social or individual factor which determine how the effectual 'dividers' of the legal system express the needs of the legal system.

${ }^{14} I d .92$. 
There are three determinants of the final result, of which the first two appear from the beginning as inseparably interrelated:

a) The final basis of the structure of the legal system lies in the socioeconomic relations.

b) A social fact becomes legal fact only by integrating in the legal complex. This complex, however cannot 'smack itself on the face', social facts have to be 'transcribed' in law according to the functions of law in compliance with the interests of the ruling class. These functions require the transformation of the social facts into teleological propositions of a concrete practical program. The relatively autonomous regularities of law formed in this way specify the integration of social facts in the system of law, and, in turn specify the second determinative element of the structure of the legal system, permanently leading to contradictions.

c) The expression of law is not exempt of the intrigues of false consciousness, i.e. the expression of law may be 'good or bad'. At this point, deformations may be brought about by elements which are accidental from the perspective of the legal system but well determined on another line. This third determinative element relating to the division of the legal system is nothing else but the inadequate expression deriving from the abovementioned transcription." 15

Eörsi put the question whether the scientific-technical revolution makes the theoretical conception about the necessity of the division of law into homogeneous branches needless. Modern western pragmatism takes the distinction between branch of law and discipline for unnecessary because it does not hold for important whether a branch of law consists of homogeneous institutions of law.

The dogmatic conception of the division of branches of law resulted also in the remission of the entire division problem into the mere practice.

Finally, Eörsi concluded that the tension between the structure of the relations to be regulated and the structure of the legal system was increasing because socio-economic relations become more and more complex. This fact influences but does not eliminate the requirement that the legal system should have a structure suitable to its own regularities. This influence consists in the formation of quasi-branches of law which are still founded on genuine branches of law based on legal homogeneity.

Eörsi's final conclusion, the summit of the development of the theory of complexity is the following:

${ }^{15}$ Id. 90-96. 
"However, beside branches of law the socialist conception recognises fields of law-usually called disciplines, but it is perhaps better to reserve the expression 'discipline' for a category of education and to speak here about quasi-branches of law-which form a unit from political or practical point of view without being branches of law. From a legal point of view these are characterised by internal complexity: they organise legally heterogeneous elements around a circumscribed socio-economic purpose. This conception subsisted especially about the legally heterogeneous land law. Furthermore, many regarded the law of agricultural co-operatives (which does not include every co-operative nor the entire agriculture) as such a field. Environmental law etc. may grow to such quasi-branches too.

In this way, according to the socialist conception, law is primarily divided into legally homogeneous branches of law on an objective basis and secondarily, so to say "under the branches of law" it mixes the tools and methods of different branches, establishes legally heterogeneous complex domains or cuts out legal fields to unite certain complexes of relations for practical purposes, irrespective of the requirement of the legal homogeneity of the system. The system of legislation corresponds to this conception as it unites, although not in their entirety, the branches of law in principal codes, supplementing it by the complex regulation of certain fields of law."16

We have accompanied Gyula Eörsi, the greatest Hungarian civilist of the second half of the twentieth century along his way, clearly not free of internal struggle, dealing with the recognition of economic law until he arrived to reconcile the purity of his theoretical views with the manifest serious requirements of the social practice. He was able to do that without need to recant his former views. He did not have to do so because he had not taken part in the witchhunt at the beginning of the 1950's, even if he had not "compromised himself" with works on economic law. His views and debating manners were all along resolute but conciliatory to the opposing views at the same time.

It is not my duty to evaluate his oeuvre here. I would not even entertain it. First, being without an aptitude for it and second because, owing to our sixtyyear-long friendship started at the school-bench I miss the necessary impartiality to do that. But I can undoubtedly assert that his magnificent oeuvre contains some works (e.g. his theory of responsibility) which are more important than the ones reviewed here. But still these certify his great factual knowledge and legal creativity.

Eörsi's oeuvre was regrettably interrupted too much early. Within the field of the law of economy it was for his disciples to continue and accomplish it.

${ }^{16} I d .116$. 